\title{
COVID-19: ICU delirium management during SARS-CoV-2 pandemic_pharmacological considerations
}

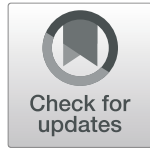

\author{
Lauren J. Andrews ${ }^{*}$ D and Scott T. Benken
}

The recent article by Kotfis and colleagues provides great insight regarding newly identified COVIDrelated risk factors contributing to ICU delirium, while also presenting valid potential solutions to barriers surrounding the implementation of the $\mathrm{ABC}$ DEF safety bundle for ICU liberation [1]. However, we feel that the omission of pertinent medication availability and selection limitations currently afflicting healthcare teams around the world warrants further discussion.

In the setting of medication shortages and anecdotally high sedation requirements in COVID patients, it has become increasingly necessary to utilize various combinations of second-line and adjunct therapy options in order to maintain appropriate levels of sedation, with indications for neuromuscular blockade and prone positioning further exacerbating this need [1]. Keeping the known sedation limitations of dexmedetomidine in mind [2], clinicians may be more inclined to use benzodiazepine infusions if unable to obtain adequate supplies of common first-line agents (e.g., fentanyl, propofol). Despite the well-documented association between benzodiazepines and delirium, this approach may be unavoidable for a large number of institutions. Ketamine may be a possible solution, however, as more data has recently emerged regarding its safety and efficacy as an adjunct therapy for analgosedation [3].

This comment refers to the article available at https://doi.org/10.1186/ s13054-020-02882-x.

* Correspondence: ljandre7@uic.edu

Department of Pharmacy Practice, University of Illinois at Chicago College of Pharmacy, 833 South Wood Street, RM 164 MC 886, Chicago, IL 60612-7230, USA

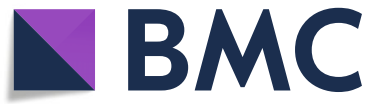

(c) The Author(s). 2020 Open Access This article is licensed under a Creative Commons Attribution 4.0 International License, which permits use, sharing, adaptation, distribution and reproduction in any medium or format, as long as you give appropriate credit to the original author(s) and the source, provide a link to the Creative Commons licence, and indicate if changes were made. The images or other third party material in this article are included in the article's Creative Commons licence, unless indicated otherwise in a credit line to the material. If material is not included in the article's Creative Commons licence and your intended use is not permitted by statutory regulation or exceeds the permitted use, you will need to obtain permission directly from the copyright holder. To view a copy of this licence, visit http://creativecommons.org/licenses/by/4.0/ The Creative Commons Public Domain Dedication waiver (http://creativecommons.org/publicdomain/zero/1.0/) applies to the data made available in this article, unless otherwise stated in a credit line to the data. 


\section{Authors' response}

Katarzyna Kotfis, Shawniqua Williams Roberson, Jo Ellen Wilson, Wojciech Dabrowski, Brenda T. Pun, and E. Wesley Ely

\section{Dear Editor,}

We appreciate the thoughts and questions posed by Dr. Andrews and Dr. Benken about pharmacological considerations related to our manuscript entitled, "COVID-19: ICU delirium management during SARS-CoV-2 pandemic." We agree wholeheartedly that resource constraints and drug shortages posed by the pandemic mandate that we develop alternative means by which to keep patients safe and comfortable while they are suffering on life support from severe acute respiratory distress syndrome (ARDS), shock, and other types of organ dysfunction. The rise in benzodiazepine use was especially disheartening, as we know that this creates a very high likelihood of our patients spending more time being delirious. This, in turn, increased the risk of acquired dementia and other elements of post-intensive care syndrome (PICS) resulting from immobilization that commonly occurs when someone is profoundly delirious.

The authors suggest that ketamine, valproic acid, and clonidine are more appropriate options than antipsychotics. In some circumstances, that may very well be true, and we are not inclined to disagree outright other than to say that there is a paucity of data upon which to base such a decision. In fact, we know of not a single randomized controlled trial that would support such a decision. Anecdote and expert opinion do serve a place in difficult times, and the COVID-19 pandemic has most certainly in some hospitals and scenarios created desperation. We believe, however, that such deviations from data should be the exception rather than the rule. In this case given by Dr. Andrews and Dr. Benken, the double use of hydroxychloroquine and azithromycin itself must be questioned as unsupported by data, and thus, first why increase the likelihood of QTc prolongation by these two anecdotally chosen agents. Perhaps instead they should be removed from the patient's regimen unless they are part of an ongoing clinical trial or some convincing evidence for their benefit becomes available. At the time of this writing, there is not enough data to support this decision. Though it is now known that antipsychotics do not treat delirium itself [6-9], it is the case that they did not increase the risk of torsades de pointes or have other notable safety issues in the clinical trials recently published.

\section{Acknowledgements}

Not applicable

\section{Authors' contributions}

Each author has made substantial contributions to this letter and has approved the submitted version. The author(s) read and approved the final manuscript.
Funding

Not applicable

Availability of data and materials

Not applicable

Ethics approval and consent to participate

Not applicable

Consent for publication

Not applicable

Competing interests

Not applicable

Received: 29 May 2020 Accepted: 8 June 2020

Published online: 23 June 2020

References

1. Kotfis K, Williams Roberson S, Wilson JE, Dabrowski W, Pun BT, Ely EW. COVID-19: ICU delirium management during SARS-CoV-2 pandemic. Crit Care. 2020;24(1):176. Published 2020 Apr 28. https://doi.org/10.1186/s13054020-02882-x.

2. Shehabi Y, Howe BD, Bellomo R, et al. Early sedation with dexmedetomidine in critically ill patients. N Engl J Med. 2019;380(26):250617. https://doi.org/10.1056/NEJMoa1904710.

3. Garber PM, Droege CA, Carter KE, Harger NJ, Mueller EW. Continuous infusion ketamine for adjunctive analgosedation in mechanically ventilated, critically ill patients. Pharmacotherapy. 2019;39(3):288-96. https://doi.org/10. 1002/phar.2223.

4. Long B, Brady WJ, Koyfman A, Gottlieb M. Cardiovascular complications in COVID-19. Am J Emerg Med. 2020. https://doi.org/10.1016/j.ajem.2020.04. 048.

5. Gagnon DJ, Fontaine GV, Riker RR, Fraser GL. Repurposing valproate, enteral clonidine, and phenobarbital for comfort in adult ICU patients: a literature review with practical considerations. Pharmacotherapy. 2017;37(10):1309-21. https://doi.org/10.1002/phar.2017.

6. Girard TD, Pandharipande PP, Carson SS, Schmidt GA, Wright PE, Canonico AE, Pun BT, Thompson JL, Shintani AK, Meltzer HY, et al. Feasibility, efficacy, and safety of antipsychotics for intensive care unit delirium: the MIND randomized, placebo-controlled trial. Crit Care Med. 2010;38(2):428-37.

7. Page VJ, Ely EW, Gates S, Zhao XB, Alce T, Shintani A, Jackson J, Perkins GD, McAuley DF. Effect of intravenous haloperidol on the duration of delirium and coma in critically ill patients (Hope-ICU): a randomised, double-blind, placebo-controlled trial. Lancet Respir Med. 2013;1(7):515-23.

8. Girard TD, Thompson JL, Pandharipande PP, Brummel NE, Jackson JC, Patel MB, Hughes CG, Chandrasekhar R, Pun BT, Boehm LM, et al. Clinical phenotypes of delirium during critical illness and severity of subsequent long-term cognitive impairment: a prospective cohort study. Lancet Respir Med. 2018;6(3):213-22.

9. van den Boogaard M, Slooter AJC, Bruggemann RJM, Schoonhoven L, Beishuizen A, Vermeijden JW, Pretorius D, de Koning J, Simons KS, Dennesen PJW, et al. Effect of haloperidol on survival among critically ill adults with a high risk of delirium: the REDUCE randomized clinical trial. JAMA. 2018;319(7):680-90.

\section{Publisher's Note}

Springer Nature remains neutral with regard to jurisdictional claims in published maps and institutional affiliations. 